\title{
Smoking during pregnancy and harm reduction in birth weight: a cross-sectional study
}

\author{
Mariana Caricati Kataoka ${ }^{1}$, Ana Paula Pinho Carvalheira ${ }^{1 *}$, Anna Paula Ferrari ${ }^{1}$, Maíra Barreto Malta ${ }^{1}$, \\ Maria Antonieta de Barros Leite Carvalhaes ${ }^{1}$ and Cristina Maria Garcia de Lima Parada ${ }^{2}$
}

\begin{abstract}
Background: Different studies have shown the advantages of abstinence from cigarette smoking during pregnancy to promote full fetal development. Given that pregnant women do not always abstain from smoking, this study aimed to analyze the effect of different intensities of smoking on birth weight of the newborn.

Methods: A cross-sectional study was adopted to explore smoking in a population of pregnant women from a mediumsized city in São Paulo state, Brazil, who gave birth between January and June of 2012. Data were collected from maternal and pediatric medical files and, where data were absent, they were collected by interview during hospitalization for delivery. For data analysis, the effect of potential confounding variables on newborn birth weight was estimated using a gamma response model. The effect of the identified confounding variables was also estimated by means of a gamma response regression model.
\end{abstract}

Results: The prevalence of smoking during pregnancy was $13.4 \%$ in the study population. In full-term infants, birth weight decreased as the category of cigarette number per day increased, with a significant weight reduction as of the category 6 to 10 cigarettes per day. Compared with infants born to non smoking mothers, mean birth weight was $320 \mathrm{~g}$ lower in infants whose mothers smoked 6 to 10 cigarettes per day and $435 \mathrm{~g}$ lower in infants whose mothers smoked 11 to 40 cigarettes per day during pregnancy.

Conclusions: Based on the study results and the principle of harm reduction, if a pregnant woman is unable to quit smoking, she should be encouraged to reduce consumption to less than six cigarettes per day.

Keywords: Pregnancy, Smoking, Tobacco use cessation, Birth weight

\section{Background}

Since the adoption of the Framework Convention on Tobacco by member countries of the World Health Organization in 2003, there have been important global actions to control smoking. Despite this, the smoking "epidemic" has grown in some countries because of the marketing power of the tobacco industry, population growth in countries with extensive consumption, and the number of highly dependent people who are unable to quit smoking [1].

\footnotetext{
* Correspondence: nana_carvalheira@hotmail.com

${ }^{1} J$ ulio de Mesquita Filho Paulista State University, Campus Universitário de

Rubião Júnior, s/n CEP, Botucatu 18618-970, Brazil

Full list of author information is available at the end of the article
}

The Centers for Disease Control and Prevention has estimated that $19.0 \%$ of American adults smoked cigarettes in 2011 [2]. The Special Survey on Smoking, a supplement to the 2008 Brazilian National Household Sample Survey, reported a smoking prevalence rate of $17.2 \%$ for people aged 15 years or older [3]. In the adult population of 27 Brazilian cities, $14.8 \%$ were smokers, and the frequency was greater for men (18.1\%) than for women (12.0\%) [4].

It is known that smoking can cause lung and other cancers, heart disease, stroke and many other diseases [2]. When associated with pregnancy, tobacco consumption can have even more severe effects, potentially compromising not only maternal health, but also fetal health and viability [5]. In the United States, about $20 \%$ of women are smokers at the beginning of pregnancy; however, $30.2 \%$ to 
$61 \%$ give up smoking in the prenatal period [6]. Women who are able to quit tend to have been light smokers [7]. There are no national Brazilian data on the prevalence of smoking during pregnancy, nor are there estimates on smoking cessation during pregnancy; however, a populationbased study carried out in Santa Maria, southern Brazil, reported that $23 \%$ of pregnant women were smokers [8].

Cigarettes are among the most frequently used drugs in pregnancy [9]. A Brazilian study identified greater chance of smoking during pregnancy in women with a higher number of previous pregnancies and who did not undergo prenatal care [8].

Smoking in pregnancy is also associated with cognitive disabilities in the newborn, slower fetal growth, abortion and premature birth $[8,9]$.

The mechanisms through which smoking leads to negative effects during pregnancy have not been fully understood. Nicotine likely plays an important role. Nicotine causes reduction in uteroplacental circulation, leading to lower maternal weight gain and in turn, negative fetal outcomes, such as small size for gestational age, low birth weight, short stature and compromised fetal neurological development. Additionally, cigarettes and their smoke contain more than 4000 potentially toxic substances, and the combination of these toxins in cigarette smoke may be the main factor responsible for health damage [10].

Other important negative effects of smoking are seen in pregnancy and the postpartum period. During pregnancy, smoking compromises local and systemic immune responses, which in turn may be associated with adverse pregnancy outcomes [11]. Postpartum, cigarettes can cause early cessation of breastfeeding and consequences for child health and development [12].

Although there are countless studies in the literature confirming the relationship between smoking and low birth weight, they have not considered the dose-response effect of smoking on low birth weight $[5,8,13]$. In view of the high prevalence of smoking during pregnancy in Brazil, the high likelihood of adverse perinatal consequences and the difficulty of quitting, this study aimed to analyze the effect of different intensities of smoking on birth weight of the newborn.

\section{Methods}

This cross-sectional study evaluated smoking in pregnant women from 13 small towns belonging to the "Colegiado Pólo Cuesta", a health network in Botucatu, a medium-sized city (140,000 inhabitants) in southeastern São Paulo, Brazil.

In Botucatu, the Public Health Service operates 18 primary care units that provide basic health care and other health services. Childbirth care is provided by specialty obstetrics and neonatology services at a university referral hospital, which has 40 beds for pregnant/puerperal women,
24 beds for newborns, 30 beds in the Intensive Care Unit (ICU) for adults and 15 beds for neonates.

In addition to public health services, private health insurance and services are also available in Botucatu. There is one private maternity hospital with 16 beds for pregnant/puerperal women, six beds for newborns and an additional 10 beds in the ICU for both adults and neonates.

Systematic sampling was used in this study: all pregnant women admitted to give birth at either of the two maternity hospitals during the study period from January 1 to June 30, 2012, were considered eligible for the study. Only women pregnant with a single fetus were included in the study. A total of 1404 pregnant/puerperal women met those conditions. Seven women refused to participate and 84 were discharged before data collection was possible; thus, the final sample consisted of 1313 pregnant/puerperal women, representing $93.5 \%$ of the eligible study population.

All subjects gave informed written consent prior to their participation in the study, in accordance with established principles of research ethics. The study was approved by the Research Ethics Committee of Botucatu Medical School (approval number 004/2013).

The variable under investigation was smoking during pregnancy (classified as: no; yes, from 1 to 5 cigarettes per day; yes, from 6 to 10 cigarettes per day and yes, from 11 to 40 cigarettes per day. With this option, the study aimed to analyze the effect of different intensities of smoking on birth weight of the newborn compared to the birth weight of newborns from nonsmoker pregnant women. Smoking during pregnancy data were obtained from medical records (56.3\%) and when they were not recorded, they were obtained during interviews (43.7\%) with the puerperal women in the hospital where the birth took place. In the interviews, the question asked was: "Do/Did you smoke during gestation period? If so, how many cigarettes do/did you usually smoke per day". For both forms of data collection, women who reported having smoked just as they did not know they were pregnant or for a short period of gestation $(n=6)$ were classified as non-smoking. Women classified as smokers during gestation were those who reported having maintained this habit throughout pregnancy.

Data were also collected on potentially confounding sociodemographic, medical and behavioral variables. Sociodemographic variables included: age (classified as $\leq 19$ years, 20-34 years, $\geq 35$ years); education ( $\leq 8$ years, $9-11$ years, $\geq 12$ years); paid employment (yes/no); and presence of a partner (yes/no). Medical variables included data on obstetrical history, namely: first pregnancy, yes/no; the interval between deliveries, only for multiparous women $(\leq 2$ years, $3-5$ years, $\geq 6$ years); and pregestational overweight or obesity (based on body mass index and classified according to the Institute of Medicine) [14] (yes/no). The quality of prenatal care was also investigated using the variables: place 
of care (public service facility, private service facility); number of medical visits (observing that seven visits are proposed as minimum by the Brazilian Ministry of Health), ( $<7$ visits, $7-14$ visits, $\geq 15$ visits, subsequently classified into $<7$ visits, $\geq 7$ visits); participation in a prenatal educational group (yes/no); previous advice regarding warning signs in pregnancy (yes/no); and use of both folic acid (as of the first prenatal visit) and iron sulfate (as of the 20th week of gestation)(yes/no). Finally, the presence of any problems during gestation (yes/no) was investigated, including emotional problems; alcoholic beverage consumption; use of illegal drugs; anemia; high blood pressure, pre-eclampsia, eclampsia, or hemolysis, elevated liver enzymes, low platelet count (HELLP) syndrome; diabetes; hyperemesis; hemorrhage, bleeding, or threatened abortion; and infection, such as syphilis, urinary tract infection, toxoplasmosis, human immunodeficiency virus (HIV), or hepatitis.

Infant data were also collected to evaluate effects. The outcome variable was birth weight (g). Given the close relationship between birth weight and gestational age, the effects of smoking on term and premature newborns were studied separately $[15,16]$; therefore, data were also collected on the birth condition (preterm, full-term) for stratification.

Just as for the data on smoking, all these other data were obtained from maternal or infant medical records (including prenatal care cards and records from the delivery room or the nursery) during hospital admission for delivery. Data that were not recorded were obtained by interview with the pregnant/puerperal women, also during hospital admission.

All data were collected by authorized health service professionals, under the supervision of a doctoral student in public health who was responsible for quality control. The data were input to a database and checked for consistency before statistical analysis.

The data analyses were performed in two phases. First, the effect of each possible confounding variable on newborn weight was estimated using a univariate gamma response model (crude analysis); variables with $p<0.20$ were chosen as potential confounders for inclusion in the following multivariate analysis. In the second phase, the smoking effect, corrected for the effect of the identified confounders, was estimated using a gamma response regression model (adjusted analysis). This model was selected for its ability to simultaneously estimate the main effect and correct for the effect of potential confounders (following the asymmetric probability distribution of the outcome). Relationships were considered significant if $p<0.05$. All analyses were performed using the Statistical Package for the Social Sciences SPSS v 20.0.

\section{Results}

Most study participants were aged $20-34$ years and had 8 to 11 years of school attendance. Considering premature and term newborns, most mothers lived with a partner respectively), employed ( $49.7 \%$ and $56.5 \%$, respectively), were multiparous $(57.1 \%$ and $62.0 \%$, respectively) and prenatal follow-up had been provided by public services (75.1\% and 70.4\%, respectively). Among the women who had preterm delivery $(n=189), 59.3 \%$ had attended $\leq 7$ medical visits; among those who delivered at term $(n=1124)$, 73.2\% had attended 8-14 prenatal visits.

The prevalence of smoking was $18.0 \%$ among mothers of premature infants and $12.6 \%$ among mothers of term infants. In both groups, the median of the number of cigarettes smoked per day ranged from 1 to 40 cigarettes/ day. The preterm birth rate was $14.4 \%$. Median birth weight was $2410 \mathrm{~g}$ and $3250 \mathrm{~g}$ for premature and full-term infants, respectively (Table 1 ).

The relationship between potential confounders and weight of premature infants is also shown in Table 2 . Attendance at $\geq 7$ prenatal medical visits; participation in a prenatal educational group; presence of emotional problems; high blood pressure, pre-eclampsia, eclampsia or HELLP syndrome; hyperemesis; hemorrhage, bleeding or threatened abortion; and infection during pregnancy were all identified as possible confounders $(p<0.20)$.

The relationship between smoking during pregnancy and birth weight of premature infants, adjusted for potential confounders (adjusted analysis), is shown in Table 3. Again, no significant difference in birth weight was found in relation to smoking.

In contrast, in full-term infants the following potential confounding factors $(p<0.20)$ were identified: presence of a partner; first pregnancy; interval between deliveries; attendance at $\geq 7$ prenatal visits; emotional problems during pregnancy; age at delivery; illegal drug use; anemia; high blood pressure, pre-eclampsia, eclampsia or HELLP syndrome; hyperemesis; and infection during pregnancy (Table 4).

The independent effect of smoking intensity on birth weight was estimated correcting for the potential confounding variables in the adjusted regression model (Table 5). Newborn weight decreased as the category of number of cigarettes per day increased, with a significant reduction at the 6 to 10 cigarettes: when mothers smoked 6 to 10 cigarettes per day, infant weight was $320.41 \mathrm{~g}$ (CI $95 \%=-535.51$ to $-105,32$ ) lower than that of infants born to nonsmoker mothers; when mothers smoked 10 to 40 cigarettes per day, infant weight was $435.01 \mathrm{~g}$ (CI 95\% $=-733.16$ to $-136,87$ ) lower than that of infants born to nonsmoker mothers. When the mother smoked during pregnancy up to 5 cigarettes per day there was no effect on birth weight $(p=0.715)$.

\section{Discussion}

This study evaluated the prevalence of smoking and the relationship between birth weight and smoking intensity in a population of women who gave birth in a medium-sized 
Table 1 Sociodemographic, medical and prenatal characteristics, and smoking status of pregnant women in Botucatu, Brazil

\begin{tabular}{|c|c|c|c|c|}
\hline \multirow[t]{2}{*}{ Variable } & \multicolumn{2}{|c|}{ Preterm delivery $(n=189)$} & \multicolumn{2}{|c|}{ Term delivery $(n=1124)$} \\
\hline & $\mathrm{N}$ & $\%$ & $\mathrm{~N}$ & $\%$ \\
\hline \multicolumn{5}{|l|}{ Age (years) } \\
\hline$\leq 19$ & 37 & 19.6 & 183 & 16.3 \\
\hline $20-34$ & 130 & 68.8 & 811 & 72.2 \\
\hline$\geq 35$ & 22 & 11.6 & 130 & 11.6 \\
\hline \multicolumn{5}{|l|}{ Education (years) } \\
\hline$\leq 8$ & 54 & 28.6 & 343 & 30.5 \\
\hline $9-11$ & 118 & 62.4 & 633 & 56.3 \\
\hline$\geq 12$ & 16 & 8.5 & 147 & 13.1 \\
\hline No information & 1 & 0.5 & 1 & 0.1 \\
\hline \multicolumn{5}{|l|}{ Employed } \\
\hline Yes & 94 & 49.7 & 635 & 56.5 \\
\hline No & 93 & 49.2 & 489 & 43.5 \\
\hline No information & 2 & 1.1 & 0 & 0.0 \\
\hline \multicolumn{5}{|l|}{ Live with a partner } \\
\hline Yes & 157 & 84.0 & 949 & 84.4 \\
\hline No & 30 & 15.9 & 168 & 15.0 \\
\hline No information & 2 & 1.1 & 7 & 0.6 \\
\hline \multicolumn{5}{|l|}{ First pregnancy } \\
\hline Yes & 81 & 42.9 & 427 & 38.0 \\
\hline No & 108 & 57.1 & 697 & 62.0 \\
\hline \multicolumn{5}{|c|}{ Interval between deliveries (years) ${ }^{a}$} \\
\hline$\leq 2$ & 28 & 25.9 & 145 & 20.8 \\
\hline $3-5$ & 34 & 31.5 & 254 & 36.5 \\
\hline$\geq 6$ & 38 & 35.2 & 272 & 39.0 \\
\hline No information & 8 & 7.4 & 26 & 3.7 \\
\hline \multicolumn{5}{|c|}{ Pregestational obesity or overweight } \\
\hline Yes & 68 & 36.0 & 353 & 31.4 \\
\hline No & 121 & 64.0 & 771 & 68.6 \\
\hline \multicolumn{5}{|c|}{ Prenatal care in public service } \\
\hline Yes & 142 & 75.1 & 791 & 70.4 \\
\hline No & 44 & 23.3 & 333 & 29.6 \\
\hline No information & 3 & 1.6 & 0 & 0.0 \\
\hline \multicolumn{5}{|c|}{ Number of prenatal medical visits } \\
\hline$\leq 7$ & 86 & 45.5 & 136 & 12.1 \\
\hline 8 to 14 & 81 & 42.9 & 923 & 82.1 \\
\hline$\geq 15$ & 4 & 2.1 & 18 & 1.6 \\
\hline No information & 18 & 9.5 & 47 & 4.2 \\
\hline \multicolumn{5}{|c|}{ Alcohol consumption } \\
\hline Yes & 9 & 4.8 & 46 & 4.1 \\
\hline No & 179 & 94.7 & 1076 & 95.7 \\
\hline No information & 1 & 0.5 & 2 & 0.2 \\
\hline \multicolumn{5}{|l|}{ Illegal drug use } \\
\hline Yes & 5 & 2.6 & 9 & 0.8 \\
\hline No & 184 & 97.4 & 1115 & 99.2 \\
\hline
\end{tabular}

Participation in prenatal group 
Table 1 Sociodemographic, medical and prenatal characteristics, and smoking status of pregnant women in Botucatu, Brazil (Continued)

\begin{tabular}{|c|c|c|c|c|}
\hline \multirow[t]{2}{*}{ Variable } & \multicolumn{2}{|c|}{ Preterm delivery $(n=189)$} & \multicolumn{2}{|c|}{ Term delivery $(n=1124)$} \\
\hline & $\mathrm{N}$ & $\%$ & $\mathrm{~N}$ & $\%$ \\
\hline Yes & 51 & 27.0 & 240 & 21.4 \\
\hline No & 126 & 66.7 & 831 & 73.9 \\
\hline No information & 12 & 6.3 & 53 & 4.7 \\
\hline \multicolumn{5}{|l|}{ Advised regarding warning signs } \\
\hline Yes & 112 & 59.3 & 724 & 64.4 \\
\hline No & 74 & 39.1 & 393 & 35.0 \\
\hline No information & 3 & 1.6 & 7 & 0.6 \\
\hline \multicolumn{5}{|l|}{ Use of folic acid and iron sulfate } \\
\hline Yes & 104 & 55.0 & 681 & 60.6 \\
\hline No & 55 & 29.1 & 443 & 39.4 \\
\hline No information & 30 & 15.9 & 0 & 0.0 \\
\hline \multicolumn{5}{|l|}{ Emotional problems } \\
\hline Yes & 31 & 16.4 & 179 & 15.9 \\
\hline No & 158 & 83.6 & 940 & 83.6 \\
\hline No information & 0 & 0.0 & 5 & 0.5 \\
\hline \multicolumn{5}{|l|}{ Anemia } \\
\hline Yes & 5 & 2.6 & 55 & 4.9 \\
\hline No & 184 & 97.4 & 1069 & 95.1 \\
\hline \multicolumn{5}{|c|}{ High blood pressure/pre-eclampsia/eclampsia/ HELLP syndrome ${ }^{b}$} \\
\hline Yes & 33 & 17.5 & 58 & 5.2 \\
\hline No & 156 & 82.5 & 1066 & 94.8 \\
\hline \multicolumn{5}{|l|}{ Diabetes } \\
\hline Yes & 9 & 4.8 & 42 & 3.7 \\
\hline No & 180 & 95.2 & 1082 & 96.3 \\
\hline \multicolumn{5}{|l|}{ Hyperemesis } \\
\hline Yes & 7 & 3.7 & 30 & 2.7 \\
\hline No & 182 & 96.3 & 1094 & 97.3 \\
\hline \multicolumn{5}{|l|}{ Hemorrhage/bleeding/ threatened abortion } \\
\hline Yes & 19 & 10.1 & 49 & 4.4 \\
\hline No & 170 & 89.9 & 1075 & 95.6 \\
\hline \multicolumn{5}{|l|}{ Infection } \\
\hline Yes & 34 & 18.0 & 222 & 19.8 \\
\hline No & 155 & 82.0 & 902 & 80.2 \\
\hline \multicolumn{5}{|l|}{ Smoking in pregnancy } \\
\hline No & 155 & 82.0 & 982 & 87.4 \\
\hline Yes, 1 to 5 cigarettes per day & 8 & 4.2 & 41 & 3.6 \\
\hline Yes, 6 to 10 cigarettes per day & 10 & 5.3 & 56 & 5.0 \\
\hline Yes, 11 to 40 cigarettes per day & 14 & 7.4 & 30 & 2.7 \\
\hline No information & 2 & 1.1 & 15 & 1.3 \\
\hline Birth weight, median (1st and 3rd quartile) (g) & \multicolumn{2}{|c|}{$2410(1845-2810)$} & \multicolumn{2}{|c|}{$3250(2975-3565)$} \\
\hline
\end{tabular}

${ }^{a}$ Total of 108 women with preterm delivery and 697 women with term delivery

${ }^{\mathrm{b}}$ HELLP hemolysis, elevated liver enzymes, low platelet count 
Table 2 Univariate analysis of possible confounding variables influencing birth weight, in premature infants $(n=189)$

\begin{tabular}{|c|c|c|c|c|}
\hline Variable & $\beta$ & SE & $p$ & $\mathrm{Cl}(\beta ; 95 \%)$ \\
\hline Age at delivery (years) & 5.5 & 18.0 & 0.762 & $(-30.4$ to 41.3$)$ \\
\hline$\leq 8$ years of education & -282.55 & 262.65 & 0.282 & $(-797.3$ to 232.24$)$ \\
\hline 9 to 11 years of education & -100.97 & 251.11 & 0.688 & $(-593.14$ to 391.19$)$ \\
\hline Employed & 124.2 & 203.2 & 0.543 & $(-281.7$ to 530.2$)$ \\
\hline Live with a partner & 210.8 & 337.2 & 0.534 & $(-462.7$ to 884.4$)$ \\
\hline First pregnancy & 8.0 & 24.7 & 0.745 & $(-41.2$ to 57.3$)$ \\
\hline Interval between deliveries (years) & 79.3 & 192.8 & 0.682 & $(-305.8$ to 464.3$)$ \\
\hline Pregestational obesity or overweight & -136.5 & 114.3 & 0.234 & $(-361.9$ to 89.0$)$ \\
\hline Prenatal care in public service & 39.0 & 147.9 & 0.793 & $(-253.8$ to 331.7$)$ \\
\hline$\geq 7$ prenatal medical visits ${ }^{b}$ & 401.7 & 111.7 & 0.000 & (180.5 to 622.9$)$ \\
\hline Alcohol consumption & -210.7 & 279.1 & 0.452 & $(-763.2$ to 341.7$)$ \\
\hline Illegal drug use & 97.9 & 682.7 & 0.886 & $(-1253.5$ to 1449.2$)$ \\
\hline Participation in prenatal group ${ }^{\mathrm{b}}$ & 203.1 & 118.6 & 0.089 & $(-31.7$ to 437.9$)$ \\
\hline Advised regarding warning signs & -5.3 & 114.0 & 0.963 & $(-230.9$ to 220.3$)$ \\
\hline Use of folic acid and iron sulfate & -49.7 & 128.6 & 0.700 & $(-304.3$ to 204.9$)$ \\
\hline Emotional problems ${ }^{\mathrm{b}}$ & 321.0 & 223.3 & 0.154 & $(-122.5$ to 764.5$)$ \\
\hline Anemia & -465.7 & 449.7 & 0.303 & $(-1358.9$ to 427.5$)$ \\
\hline High blood pressure/pre-eclampsia/ eclampsia/ HELLP syndromea, b & -469.5 & 303.7 & 0.126 & $(-1072.7$ to 133.6$)$ \\
\hline Diabetes & 314.7 & 328.7 & 0.341 & $(-338.2$ to 967.6$)$ \\
\hline Hyperemesis $^{\mathrm{b}}$ & -690.8 & 437.4 & 0.118 & $(-1559.5$ to 177.9$)$ \\
\hline Hemorrhage/ bleeding/threatened abortion ${ }^{\mathrm{b}}$ & -442.1 & 321.8 & 0.173 & $(-1081.3$ to 197.1$)$ \\
\hline Infection ${ }^{b}$ & -522.3 & 300.1 & 0.085 & $(-1118.3$ to 73.8$)$ \\
\hline
\end{tabular}

${ }^{a} H E L L P$ hemolysis, elevated liver enzymes, low platelet count

${ }^{\text {b }}$ Selected as potential confounder

city in southeastern Brazil. The impact of tabagism was evaluated using a cathegorized pattern instead of a continuous variable, because of the irregular distribution of the variable and high proportion of zeros (nonsmoker mothers). That procedure was performed so that a dilution of the smoking effect could be avoided (mean effect), and the impact of different loads of maternal smoking could be detected: 1 to 5 cigarretes per day or light smokers, 6 to 10 or medium smokers and 11 to 40 or heavier smokers.

Analysis of the premature infant data showed no statistically significant differences between the birth weight of infants born to smoking and nonsmoking pregnant women. In contrast, the analysis of full-term infants revealed a negative, dose-response effect of smoking on newborn weight. Compared with infants born to nonsmoking mothers, mean birth weight was $320 \mathrm{~g}$ lower in newborns whose mothers smoked 6-10 cigarettes per day and $435 \mathrm{~g}$ lower in newborns whose mothers smoked 11-40 cigarettes per day during pregnancy. This effect was observed even after correction for identified potential confounders, such as maternal age, presence of a partner, parity, interval between deliveries, number of prenatal medical visits, emotional problems in pregnancy, illegal drug use, anemia, high blood pressure, hyperemesis, gestational age and infection during pregnancy. Interestingly, no statistically significant differences were found in mean birth weight when mothers smoked 1-5 cigarettes per day.

An important consideration is that the accuracy of the data on smoking and the number of cigarettes smoked per day during pregnancy may limit the validity of the study findings. It is known that the number of cigarettes smoked per day can vary throughout pregnancy [17], and this was not addressed in the cross-sectional design of the present study, which relied on self-reporting at the time of delivery or medical records. Besides, women who reported having quit the habit just at the beginning of gestation were considered as nonsmokers, and the passive exposure to tobacco smoke (non investigated) was not considered, which could result in some underestimation of the smoking effect on birth weight. Nevertheless, an important negative effect was observed.

The data are representative of a single place in the southeastern region of Brazil. The prevalence of smoking in the pregnant women that was found in our study (overall prevalence of $13.4 \%$ ) corroborates the importance of understanding its effects. The smoking prevalence among 
Table 3 Multivariate analysis of smoking and birth weight of premature infants $(n=189)$

\begin{tabular}{lllll}
\hline Variable & $\beta$ & SE & $p$ & $\mathrm{Cl}(\beta ; 95 \%)$ \\
\hline (Intercept) & - & 587.97 & 0.000 & $(-2639.07$ to -4943.86$)$
\end{tabular}

Smoking in pregnancy

$\begin{array}{llllll}\begin{array}{l}\text { Yes, } 11 \text { to } 40 \\ \text { cigarettes per day }\end{array} & -340.03 & 191.32 & 0.076 & \text { (-715.01 to } 34.94) \\ \begin{array}{l}\text { Yes, } 6 \text { to } 10 \\ \text { cigarettes per day }\end{array} & 265.27 & 403.49 & 0.511 & \text { (-525.56 to 1056.16) } \\ \begin{array}{l}\text { Yes, } 1 \text { to } 5 \\ \text { cigarettes per day }\end{array} & -475.24 & 309.48 & 0.125 & (-1081.80 \text { to } 131.34)\end{array}$

No reference

$\geq 7$ prenatal medical

visits

$\begin{array}{lllll}\text { Yes } & 394.58 & 135.28 & 0.004 & (129.44 \text { to 659.73) } \\ \text { No } & & & \text { reference }\end{array}$

Participation in prenatal group

$\begin{array}{ccccc}\text { Yes } & -27.69 & 147.23 & 0.851 & (-316.25 \text { to 260.86) } \\ \text { No } & & & \text { reference }\end{array}$

Emotional problems

$\begin{array}{ccccc}\text { Yes } & 103.30 & 197.31 & 0.601 & (-283.81 \text { to 490.41) } \\ \text { No } & & & \text { reference }\end{array}$

High blood pressure/

pre-eclampsia/

eclampsia/ HELLP

syndrome ${ }^{a}$

$\begin{array}{ccccc}\text { Yes } & -23.82 & 198.03 & 0.904 & (-411.95 \text { to 364.32) } \\ \text { No } & & & \text { reference }\end{array}$

Hemorrhage/bleeding/

threatened abortion

$\begin{array}{ccccc}\text { Yes } & 342.39 & 211.14 & 0.105 & (-71.44 \text { to } 756.21) \\ \text { No } & & & \text { reference }\end{array}$

Infection

Yes

$\begin{array}{llll}-312.23 & 186.72 & 0.094 \quad(-678.29 & \text { to } 53.63)\end{array}$

No

$\begin{array}{lllll}\begin{array}{l}\text { Gestational age } \\ \text { (weeks) }\end{array} & 180.68 & 16.32 & < & 0.001\end{array} \quad$ (148.68 to 212.67)

reference

Hyperemesis

$$
\begin{aligned}
& \text { Yes } \quad-307.98 \quad 261.780 .239 \quad(-821.06 \text { to } 205.11) \\
& \text { No reference }
\end{aligned}
$$

${ }^{\mathrm{a}}$ HELLP hemolysis, elevated liver enzymes, low platelet count

pregnant women in Botucatu was lower than that in nonpregnant adult women in São Paulo capital city (16.8\%) and higher to the average value reported in other Brazilian capitals (12\%), the only population data available for comparisons [4]. Furthermore, smoking effects are mainly a result of biological processes, and that fact also may support the generalization of our findings. Nevertheless, it is likely that in similar contexts and populations (middle-
Table 4 Univariate analyses of possible confounding variables

\begin{tabular}{|c|c|c|c|c|}
\hline Variable & $\beta$ & SE & $p$ & $\mathrm{Cl}(\beta ; 95 \%)$ \\
\hline Age at delivery (years) ${ }^{\mathrm{b}}$ & -9.9 & 4.2 & 0.018 & $(-18.1$ to -1.7$)$ \\
\hline$\leq 8$ years of education & 35.04 & 47.94 & 0.465 & $(-58.92$ to 128.99$)$ \\
\hline 9 to 11 years of education & 8.63 & 44.3 & 0.846 & $(-78.35$ to 95.62$)$ \\
\hline Employed & 24.5 & 45.6 & 0.592 & $(-65.2$ to 114.2$)$ \\
\hline Live with a partner $^{\mathrm{b}}$ & 91.9 & 69.2 & 0.185 & $(-44.1$ to 227.9$)$ \\
\hline First pregnancy ${ }^{b}$ & 9.1 & 6.0 & 0.132 & $(-2.7$ to 21.0$)$ \\
\hline $\begin{array}{l}\text { Interval between deliveries } \\
\text { (years) }^{b}\end{array}$ & 149.8 & 42.9 & 0.001 & (65.5 to 234.0$)$ \\
\hline $\begin{array}{l}\text { Pregestational obesity or } \\
\text { overweight }\end{array}$ & -55.7 & 478.5 & 0.907 & $(-995.8$ to 884.4$)$ \\
\hline $\begin{array}{l}\text { Prenatal care in public } \\
\text { service }^{b}\end{array}$ & 77.7 & 40.6 & 0.056 & $(-2.0$ to 157.3$)$ \\
\hline$\geq 7$ prenatal medical visits $^{b}$ & 108.4 & 44.7 & 0.016 & (20.7 to 196.1$)$ \\
\hline Alcohol consumption & 4.8 & 73.6 & 0.948 & $(-139.6$ to 149.2$)$ \\
\hline Illegal drug use $\mathrm{b}^{\mathrm{b}}$ & -247.6 & 170.7 & 0.147 & $(-582.6$ to 87.3$)$ \\
\hline $\begin{array}{l}\text { Participation in prenatal } \\
\text { group }\end{array}$ & -31.9 & 35.6 & 0.371 & $(-101.8$ to 38.0$)$ \\
\hline $\begin{array}{l}\text { Advised regarding } \\
\text { warning signs }\end{array}$ & -13.6 & 31.2 & 0.662 & $(-74.9$ to 47.6$)$ \\
\hline $\begin{array}{l}\text { Use of folic acid } \\
\text { and iron sulfate }\end{array}$ & 11.5 & 39.2 & 0.770 & $(-65.4$ to 88.3$)$ \\
\hline Emotional problems ${ }^{b}$ & 81.9 & 54.1 & 0.130 & $(-24.3$ to 188.2$)$ \\
\hline Anemia $^{\mathrm{b}}$ & -145.2 & 109.9 & 0.187 & $(-361.2$ to 70.8$)$ \\
\hline $\begin{array}{l}\text { High blood pressure/ } \\
\text { pre-eclampsia/eclampsia/ } \\
\text { HELLP syndrome, }, \text { b }\end{array}$ & -175.5 & 114.5 & 0.126 & (-400.5 to 49.6$)$ \\
\hline Diabetes & -132.3 & 121.2 & 0.275 & $(-370.5$ to 105.8$)$ \\
\hline Hyperemesis $^{\mathrm{b}}$ & -229.8 & 120.0 & 0.056 & $(-465.7$ to 6.1$)$ \\
\hline $\begin{array}{l}\text { Hemorrhage/bleeding/ } \\
\text { threatened abortion }\end{array}$ & -105.6 & 113.3 & 0.352 & $(-328.2$ to 117.0$)$ \\
\hline Infection ${ }^{b}$ & -165.9 & 100.4 & 0.099 & ( -363.1 to 31.4$)$ \\
\hline
\end{tabular}
influencing birth weight, in full-term infants $(n=1124)$

${ }^{\text {a HELLP }}$ hemolysis, elevated liver enzymes, low platelet count

${ }^{b} S e l e c t e d$ as potential confounder

income countries with good availability of prenatal care), tobacco use during pregnancy will negatively affect term newborn weight to a similar extension as it did in the present study.

About $40 \%$ of pregnant women are estimated to quit smoking spontaneously, primarily out of concerns for fetal health but also, out of concern for their own. Others may be encouraged to quit smoking, through concerted counseling about the risks of smoking to fetus and mother that begins at the initiation of prenatal care [18]. On the whole, pregnant women are receptive to educational measures and health promotion [17] and are more likely to consider smoking cessation in the context of the frequent contact with health professionals during prenatal care [9]. Accordingly, the prenatal protocol of the Brazilian Health Ministry [16] instructs that smoking 
Table 5 Multivariate analysis of smoking and birth weight of full-term infants $(n=1124)$

\begin{tabular}{|c|c|c|c|c|}
\hline Variable & $\beta$ & SE & $p$ & $\mathrm{Cl}(\beta ; 95 \%)$ \\
\hline (Intercept) & -750.57 & 927.63 & 0.000 & $(-2568.70$ to 1067.55$)$ \\
\hline \multicolumn{5}{|l|}{ Smoking in pregnancy } \\
\hline Yes, 11 to 40 cigarettes per day & -435.01 & 152.12 & 0.004 & $(-733.16$ to -136.87$)$ \\
\hline Yes, 6 to 10 cigarettes per day & -320.41 & 109.74 & 0.004 & $(-535.51$ to -105.32$)$ \\
\hline Yes, 1 to 5 cigarettes per day & 54.81 & 150.09 & 0.715 & (- 348.99 to 239.37$)$ \\
\hline No & & & & reference \\
\hline \multicolumn{5}{|l|}{ Live with a partner } \\
\hline Yes & 93.46 & 92.59 & 0.313 & (-88.01 to 274.920 \\
\hline No & & & & reference \\
\hline \multicolumn{5}{|l|}{ Prenatal care in public service } \\
\hline Yes & -1.10 & 72.10 & 0.988 & $(-142.42$ to 140.21$)$ \\
\hline No & & & & reference \\
\hline \multicolumn{5}{|l|}{$\geq 7$ prenatal medical visits } \\
\hline Yes & 125.21 & 80.30 & 0.119 & $(-32.18$ to 282.60$)$ \\
\hline No & & & & reference \\
\hline \multicolumn{5}{|l|}{ Illegal drug use } \\
\hline Yes & -445.41 & 385.79 & 0.248 & $(-1201.55$ to 310.73$)$ \\
\hline No & & & & reference \\
\hline \multicolumn{5}{|l|}{ Emotional problems } \\
\hline Yes & 127.67 & 72.15 & 0.077 & $(-13.74$ to 269.08$)$ \\
\hline No & & & & reference \\
\hline \multicolumn{5}{|l|}{ Anemia } \\
\hline Yes & -3.09 & 99.58 & 0.975 & $(-198.27$ to 192.09$)$ \\
\hline No & & & & reference \\
\hline \multicolumn{5}{|c|}{$\begin{array}{l}\text { High blood pressure/pre-eclampsia/eclampsia/ } \\
\text { HELLP syndrome }\end{array}$} \\
\hline Yes & 19.75 & 91.79 & 0.830 & $(-160.15$ to 199.66$)$ \\
\hline No & & & & reference \\
\hline \multicolumn{5}{|l|}{ Hyperemesis } \\
\hline Yes & -143.85 & 134.86 & 0.286 & $(-408.18$ to 120.47$)$ \\
\hline No & & & & reference \\
\hline \multicolumn{5}{|l|}{ Infection } \\
\hline Yes & -53.29 & 70.23 & 0.448 & $(-190.95$ to 84.36$)$ \\
\hline No & & & & reference \\
\hline Age at delivery (years) & -0.77 & 6.14 & 0.900 & $(-12.80$ to 11.25$)$ \\
\hline Gestational age (weeks) & 111.48 & 11.23 & $<0,001$ & $(-12.80$ to 11.25$)$ \\
\hline Interval between deliveries (years) & 4.56 & 8.04 & 0.571 & $(-11.19$ to 20.31$)$ \\
\hline
\end{tabular}

${ }^{\mathrm{a} H E L L P}$ hemolysis, elevated liver enzymes, low platelet count

pregnant women be identified in prenatal medical visits, advised to quit and offered support to achieve this goal. As such, the findings of the study population are worrying. It is likely that not all pregnant women were appropriately counseled during their medical visits. The high prevalence of smoking in the study population shows that actions to address prevention of tobacco use in general and, particularly, during prenatal care, have been inadequate in the study region.

Despite the need for smoking cessation, it may be more challenging to achieve it during pregnancy, especially considering that a powerful psychoactive drug, nicotine, causes chemical addiction to smoking [19]. Nicotine replacement therapy has been effective in helping the addicted 
population to quit smoking [20] and thus, reduces harm from smoking; however, its use during pregnancy is controversial [21]. Questions remain about long-term effects and the safety of nicotine replacement therapy during pregnancy and the postpartum period [13, 21, 22].

From the perspective of practical advice for pregnant women unable to quit smoking, the study findings support the recommendation of less than six cigarettes a day to minimize the negative effects of smoking on newborn weight; however, this must be validated with further studies evaluating the effects of reduced tobacco use on birth weight and on other outcomes, such as prematurity, stillbirth and sudden infant death syndrome.

\section{Conclusions}

The study showed that smoking during pregnancy is associated with lower birth weight in full-term infants. Smoking intensity is also important. The study found a dose-response that was significant as of the 6 to 10 cigarette-per-day category.

The high reported prevalence of smoking among women during pregnancy shows that actions to promote and support smoking cessation during pregnancy are definitely necessary in the study region. Smoke-free policies, both at a national level and globally, must remain strict, especially when related to recommendations of complete smoking cessation during pregnancy. If, however, the goal of total abstinence proves impossible, there is still an opportunity to minimize the negative effects of smoking during pregnancy on birth weight by reducing as much as possible the number of cigarettes smoked per day.

\section{Abbreviations}

HELLP: Hemolysis, elevated liver enzymes, low platelet count; HIV: Human immunodeficiency virus; ICU: Intensive Care Unit; SPSS: Statistical package for the social sciences

\section{Acknowledgements}

The authors gratefully acknowledge the São Paulo Research Foundation for funding this research.

\section{Availability of data and materials}

The authors are happy to share anonymized data related to this paper upon receiving a specific request, along with the purpose of that request. Interested parties may contact nana_carvalheira@hotmail.com.

\section{Authors' contributions}

All authors have made substantial contributions to the study, and all endorsed the data and conclusions. MCK contributed to conception and design of the study, data acquisition, and analysis and interpretation of data. APPC contributed to conception and design of the study, data acquisition, and analysis and interpretation of data; participated in writing the draft manuscript and revised it critically for important intellectual content, and gave final approval of the version to be published. APF participated in writing the draft manuscript and revised it critically for important intellectual content, and gave final approval of the version to be published. MBM participated in writing the draft manuscript and revised it critically for important intellectual content, and gave final approval of the version to be published. MABLC participated in writing the draft manuscript and revised it critically for important intellectual content, and gave final approval of the version to be published. CMGLP participated in writing the draft manuscript and revised it critically for important intellectual content, and gave final approval of the version to be published.

\section{Consent for publication}

NA

Competing interests

The authors declare that they have no competing interests.

\section{Publisher's Note}

Springer Nature remains neutral with regard to jurisdictional claims in published maps and institutional affiliations.

\section{Author details}

1Julio de Mesquita Filho Paulista State University, Campus Universitário de Rubião Júnior, s/n CEP, Botucatu 18618-970, Brazil. Nursing Department, Botucatu Medical School Julio de Mesquita Filho Paulista State University, Botucatu, Brazil.

Received: 11 January 2017 Accepted: 28 February 2018

Published online: 12 March 2018

\section{References}

1. World Health Organization. WHO report on the global tobacco epidemic, 2011. Warning about the dangers of tobacco. Geneva: World Health Organization; 2011. Available from: http://whqlibdoc.who.int/publications/ 2011/9789240687813_eng.pdf. [cited 2015 Mar 20].

2. Centers for Disease Control and Prevention (CDC). Current cigarette smoking among adults - United States, 2011. Morb Mortal Wkly Rep. 2012:61(44):889-94

3. Instituto Nacional do Câncer. Organização Pan-Americana de Saúde: Pesquisa especial de tabagismo. PETab. Relatório Brasil. Rio de Janeiro: Instituto Nacional do Câncer; 2011. Available from: bvsms.saude.gov.br/bvs/ publicacoes/pesquisa_especial tabagismo_petab.pdf

4. Ministério da Saúde, Secretaria de Vigilância em Saúde. Vigitel Brasil 2011: Vigilância de fatores de risco e proteção para doenças crônicas por inquérito telefônico. Brasília (DF): Ministério da Saúde; 2012.

5. Murin S, Rafii R, Bilello K. Smoking and smoking cessation in pregnancy, Clin Chest Med. 2011;32:75-91.

6. Tong VT, Jones JR, Dietz PM, D'Angelo D, Bombard JM. Trends in smoking before, during, and after pregnancy - pregnancy risk assessment monitoring system (PRAMS) United States, 31 sites, 20002005. MMWR Surveill Summ. 2009:58:1-29.

7. Stotts AL, Groff JY, Velasquez MM, Benjamin-Garner R, Green C, Carbonari JP et al. Ultrasound feedback and motivational interviewing targeting smoking cessation in the second and third trimesters of pregnancy. Nicotine Tob Res. 2009:11:961-8.

8. Galão AO, Soder SA, Gerhardt M, Faertes TH, Krüger MS, Pereira DF, et al. Efeitos do fumo materno durante a gestação e complicações perinatais. Rev HCPA. 2009;29:218-24.

9. Motta GCP, Echer IC, Lucena AF. Fatores associados ao tabagismo na gestação. Rev Latino-Am Enfermagem. 2010;18:08 telas.

10. Ontario Medical Association (OMA). Rethinking stop-smoking medications: treatment myths and medical realities. Ontario Med Rev. 2008;75(1):22-34. Available from: http://youcanmakeithappen.ca/wp-content/uploads/2011/ 08/2008RethinkingStop-SmokingMedications.pdf. [cited 2015 Mar 20].

11. Prins JR, Hylkema MN, JJHM E, Huitema S, Dekkema GJ, Dijkstra FE, et al. Smoking during pregnancy influences the maternal immune response in mice and humans. Am J Obstet Gynecol. 2012;207:76.e1-14.

12. Del Ciampo LA, Ricco RG, Ferraz IS, Daneluzzi JC, Martinelli Junior CE. Prevalence of smoking and alcohol consumption among mothers of infants under six months of age. Rev Paul Pediatr. 2009;27:361-5.

13. Jaddoe WW, Troe EJ, Hofman A, Mackenbach JP, Moll HA, Steegers EA, et al. Active and passive maternal smoking during pregnancy and the risks of low birthweight and preterm birth: the generation R study. Paediatr Perinat Epidemiol. 2008;22:162-71.

14. Institute of Medicine. Weight gain during pregnancy: reexamining the guidelines. Washington: Institute of Medicine; 2009. Available from: http://www.nationalacademies.org/hmd/ /media/Files/Report\%20Files/ 2009/Weight-Gain-During-Pregnancy-Reexamining-the-Guidelines/ 
Report\%20Brief\%20-\%20Weight\%20Gain\%20During\%20Pregnancy.pdf. [cited 2016 Mar 20].

15. Barros FC, Victora CG, Matijasevich A, Santos IS, Horta BL, Silveira MF, et al. Preterm births, low birth weight, and intrauterine growth restriction in three birth cohorts in southern Brasil: 1982, 1993 and 2004. Cad Saúde Pública. 2008;24(Suppl 3):S390-8.

16. World Health Organization. Guidelines on optimal feeding of low birthweight infants in low- and middle-income countries. Geneva: World Health Organization; 2011. Available from: http://www.who.int/maternal_child_ adolescent/documents/9789241548366.pdf?ua=1. [cited 2015 Mar 20].

17. da Saúde M. Secretaria de Atenção a Saúde. Cadernos de Atenção Básica: Atenção ao Pré-natal de Baixo Risco. Ministério da Saúde: Braślia (DF); 2012.

18. Reichert J, Araújo AJ, Gonçalves CMC, Godoy I, Chatkin JM, Sales MPU, et al. Diretrizes para cessação do tabagismo. J Bras Pneumol. 2008;34:845-80.

19. Grief SN. Nicotine dependence: health consequences, smoking cessation therapies, and pharmacotherapy. Prim Care Clin Office Pract. 2011;38:23-39.

20. Beard E, Aveyard P, Brown J, West R. Assessing the association between the use of NRT for smoking reduction and attempts to quit smoking using propensity score matching. Drug Alcohol Depend. 2012;126:354-61.

21. Brose LS, McEwen A, West R. Association between nicotine replacement therapy use in pregnancy and smoking cessation. Drug Alcohol Depend. 2013:128:15-9

22. Bruin JE, Gerstein HC, Holloway AC. Long-term consequences of fetal and neonatal nicotine exposure: a critical review. Toxicol Sci. 2010;116:364-74.

\section{Submit your next manuscript to BioMed Central and we will help you at every step:}

- We accept pre-submission inquiries

- Our selector tool helps you to find the most relevant journal

- We provide round the clock customer support

- Convenient online submission

- Thorough peer review

- Inclusion in PubMed and all major indexing services

- Maximum visibility for your research

Submit your manuscript at www.biomedcentral.com/submit

) Biomed Central 